\title{
Semaphorin 3A Elicits Stage-Dependent Collapse, Turning, and Branching in Xenopus Retinal Growth Cones
}

\author{
Douglas S. Campbell, Aoife G. Regan, Juanita S. Lopez, David Tannahill, William A. Harris, and \\ Christine E. Holt
}

Department of Anatomy, University of Cambridge, Cambridge, CB2 3DY, United Kingdom

\begin{abstract}
The semaphorin receptor, neuropilin-1 (NP-1), was first identified in Xenopus as the A5 antigen and is expressed abundantly in developing retinal ganglion cells (RGCs). Here we show that growth cones acquire responsiveness to semaphorin 3A (Sema $3 \mathrm{~A})$ with age and that the onset of responsiveness correlates with the appearance of NP-1 immunoreactivity. Growth cones from "old" (stage 35/36) retinal explants collapse rapidly (5-10 $\mathrm{min}$ ) in response to Sema $3 \mathrm{~A}$ and turn away from a gradient of Sema 3A, whereas "young" growth cones (stage 24) are insensitive to Sema 3A. Moreover, transfection of full-length NP-1 into young neurons confers premature Sema $3 A$ sensitivity. When young neurons are aged in culture they develop Sema 3A sensitivity in parallel with those in vivo, suggesting that an intrinsic mechanism of NP-1 regulation mediates this agedependent change. Sema 3A-induced collapse is transient, and
\end{abstract}

after recovery $\sim 30 \%$ of growth cones extend new branches within $1 \mathrm{hr}$, implicating Sema $3 \mathrm{~A}$ as a branching factor. Pharmacological inhibitors were used to investigate whether these three Sema 3A-induced behaviors (collapse, turning, and branching) use distinct second messenger signaling pathways. All three behaviors were found to be mediated via cGMP. In situ hybridization shows that Sema $3 \mathrm{~A}$ is expressed in the tectum and at the anterior boundary of the optic tract where axons bend caudally, suggesting that Sema 3A/NP-1 interactions play a role in guiding axons in the optic tract and in stimulating terminal branching in the tectum.

Key words: visual system development; retinotectal projection; Xenopus; growth cone collapse; axon guidance; Sema $3 A$; neuropilin-1
During the development of the retinotectal system of lower vertebrates such as Xenopus laevis, retinal ganglion cell (RGC) axons navigate along a stereotypical pathway from the eye to the contralateral optic tectum in the midbrain (for review, see Chien and Harris, 1994; Dingwell et al., 2000). During their journey, axons must respond to molecular cues that direct steering and to cues that elicit terminal branching. A screen for tectal markers in Xenopus identified A5 as an antigen that is expressed abundantly in the developing visual projection (Takagi et al., 1987, 1991). Later named neuropilin-1 (NP-1), this molecule was subsequently found to be an essential component of the semaphorin 3A (Sema 3A) receptor (He and Tessier-Lavigne, 1997; Kolodkin et al., 1997). NP-1 expression begins in Xenopus RGC axons at stage 33/34 (Fujisawa et al., 1995), when leading retinal axons first enter the optic tract (Holt, 1984), and increases progressively as axons grow through the optic tract reaching maximum levels at stages 41-43 when axons undergo terminal arborization in the tectum. Despite its provocative expression pattern, it has not yet been shown that NP-1 plays a functional role in establishing the retinotectal pathway.

\footnotetext{
Received July 25, 2001; revised July 25, 2001; accepted Aug. 10, 2001.

We thank Hajime Fujisawa for providing the neuropilin-1 cDNA A5 and B2 antibodies, Joost Verhaagen for the AN-1 antibody, Kunimasa Ohta for the Sema 3A constructs and valuable discussions, David Turner for the pCS2+ plasmid, Karl Johnson for the pCS2+ss-myc plasmid, Asha Dwivedy for technical assistance, and Takushi Odagiri for preliminary observations. We also thank Paul Goldsmith, Kevin Dingwell, Derryck Shewan, Fanny Mann, and Chi-Bin Chien for comments on this manuscript, all members of the Holt and Harris laboratories for helpful discussions, S. Jack for reagents, and Tilak Das for moral support. This work was supported by the Medical Research Council (C.E.H., W.A.H., A.G.R., D.T.), the Biotechnology and Biological Sciences Research Council (D.S.C.), and the Royal Society (D.T.).

Correspondence should be addressed to Christine E. Holt, Department of Anatomy, Downing Street, Cambridge CB2 3DY, UK. E-mail: ceh@mole.bio.cam.ac.uk. Copyright (C) 2001 Society for Neuroscience 0270-6474/01/218538-10\$15.00/0
}

The same Xenopus tectal screen (Takagi et al., 1987) also identified another component of Sema 3A signaling, the B2 antigen later characterized as plexin (Ohta et al., 1995). The plexins are a family of receptor molecules that interact directly with NP-1 and are critical for the transduction of the Sema 3A signal (Takahashi et al., 1999; Tamagnone et al., 1999; Rohm et al., 2000). Xenopus plexin is most homologous to murine plexin-A1 (Kameyama et al., 1996) and is expressed in RGCs from stages 35/36 to at least stage 53 (Ohta et al., 1992).

The ligands for NP-1 and plexin, the semaphorins (Kolodkin, 1996), constitute a large family of secreted proteins that have been implicated in axon guidance in vertebrates and invertebrates. Sema 3A, the first vertebrate semaphorin to be discovered, was shown to cause growth cone collapse in chick dorsal root ganglion (DRG) and sympathetic chain ganglia (SCG) neurons but not in retinal neurons (Raper and Kapf hammer, 1990; Luo et al., 1993). More recently, Sema 3A has been shown to be repulsive for Xenopus spinal neurons in a chemotropic growth cone turning assay (Song et al., 1998). This repulsive response can be converted to attraction by manipulation of the intracellular cGMP signaling pathway (Song et al., 1998). A repulsive role for Sema $3 \mathrm{~A}$ in vivo is supported by the overabundant axon growth in dorsal root ganglia of Sema 3A knock-out mice (Taniguchi et al., 1997) and in the transient collapse of growth cones from the zebrafish posterior lateral line ganglion during microinjection of Sema 3A1 protein (Shoji et al., 1998).

The lack of Sema 3A sensitivity and the absence of NP-1 expression in chick retinal neurons (Raper and Kapfhammer, 1990; Luo et al., 1993; Takagi et al., 1995) has given rise to the view that Sema 3A/NP-1 signaling is not important for axon guidance in the visual system. Given that NP-1 and plexins are 
highly expressed in developing RGCs in Xenopus (Takagi et al., 1987, 1991; Ohta et al., 1992, 1995) and mouse (Kawakami et al., 1996; Murakami et al., 2001), we have reexamined this possibility in Xenopus. Here we provide the first evidence to show that RGC growth cones are responsive to Sema $3 \mathrm{~A}$ and that they exhibit collapse, branching, and repulsive turning behaviors that are age dependent and cGMP regulated. Our results indicate that in the proximal part of the pathway (retina, optic stalk/chiasm), RGC growth cones are insensitive to Sema 3A. More distally in the pathway (optic tract and tectum), however, when growth cones express NP-1, Sema 3A may modulate axon growth and stimulate terminal branching in the tectum.

\section{MATERIALS AND METHODS}

Embryos. Embryos were obtained by in vitro fertilization as described previously (Cornel and Holt, 1992), raised in 0.1× Modified Bath's Saline (MBS) at $14-25^{\circ} \mathrm{C}$, and staged according to Nieukoop and Faber (1967).

DNA constructs and subcloning. pCAGGS chick Sema 3A (Ohta et al., 1999) and pCAGGS (Niwa et al., 1991) were gifts from K. Ohta (Kumamoto University, Kumamoto, Japan). Xenopus NP-1 (a gift from H. Fujisawa, Nagoya University, Nagoya, Japan) was N terminal myc-tagged by removing the endogenous signal sequence and subcloning into pCS2+ (a gift from D. Turner, University of Michigan, Ann Arbor, MI) modified to contain an N-cadherin signal sequence and six myc tags (a gift from K. Johnson, Harvard University, Boston, MA). RT-PCR was used to clone the semaphorin domain of Sema 3A from Xenopus embryo cDNA. This fragment was then used to obtain a clone containing the full-length coding sequence from a stage 28 Xenopus cDNA library (Hemmati-Brivanlou et al., 1991) (GenBank accession no. AY030051). Chick Sema 3A and Xenopus Sema 3A share 98\% homology at the amino acid level. Xenopus Sema 3A (X-Sema 3A) was subcloned into the pCAGGS vector.

Embryo injections and capped $m R N A$. Capped mRNA was made from myc-tagged NP-1, green fluorescent protein (GFP), and GFP-myc using SP6 RNA polymerase (mMESSAGE mMACHINE, Ambion, UK) according to the manufacturer's instructions. Four nanograms of myctagged NP-1 RNA were coinjected together with 500 pg GFP RNA as a lineage tracer into one of the two blastomeres at the two-cell stage using a Picospritzer (General Valve Corporation, Fairfield, NJ). Embryos were incubated for $\sim 24 \mathrm{hr}$ at $22^{\circ} \mathrm{C}$ until stage 24 , when the eye primordia of GFP-expressing embryos were cultured as described below.

Whole-mount in situ hybridization and visualization of optic projections. RGC axons were labeled using horseradish peroxidase (HRP; Sigma, Poole, UK) and diaminobenzidine (DAB, Sigma), as described previously (Cornel and Holt, 1992). Whole-mount in situ hybridization was performed according to Shimamura et al. (1994). Sections were made by post-fixing the embryos in $0.5 \%$ glutaraldehyde $/ 4 \%$ paraformaldehyde overnight at $4{ }^{\circ} \mathrm{C}$ and dehydrated through a graded methanol series. They were washed in isopropanol for $10 \mathrm{~min}$, cleared in tetrahydronapthalene, and wax embedded according to standard protocols. Whole mounts and sections were viewed using an Axioplan compound microscope (Zeiss) and photographed using a Spot digital camera (Diagnostic Instruments).

Expression of Sema $3 \mathrm{~A}$ in COS-7 cells. Transfection of pCAGGS Sema 3A, pCAGGS X-Sema 3A, and pCAGGS (control) into COS-7 cells was performed using LipofectAMINE (Life Technologies, Gaithersburg, MD) according to the manufacturer's instructions. Supernatants were collected after $5 \mathrm{~d}$ and stored at $-80^{\circ} \mathrm{C}$.

Xenopus retinal explant culture and collapse assays. Eye primordia were dissected from stages $24,28,32,35 / 36$, and $37 / 38$ embryos and cultured as described previously (de la Torre et al., 1997). Cultures for collapse assays were grown for 6,24 , or $48 \mathrm{hr}$ at room temperature on glass coverslips precoated with $10 \mu \mathrm{g} / \mathrm{ml}$ poly-L-lysine (Sigma) and $10 \mu \mathrm{g} / \mathrm{ml}$ laminin (Sigma). For growth cone turning assays, eye primordia from stages 24 and 32 embryos were plated on coverslips precoated with 5 $\mu \mathrm{g} / \mathrm{ml}$ laminin and grown for 6-12 or $16-24 \mathrm{hr}$ at room temperature before assaying. The collapse assay was performed as described (Luo et al., 1993) with the following modifications: $100 \mu \mathrm{l}$ of Sema 3A or X-Sema 3A-containing COS-7 cell or control supernatant was added to each culture for $10 \mathrm{~min}$ at room temperature. Cultures were fixed in $2 \%$ paraformaldehyde containing $15 \%$ sucrose for a minimum of $15 \mathrm{~min}$. Each batch of Sema 3A supernatant was bioassayed with one collapsing unit $(\mathrm{CU})$, defined as the dilution of Sema $3 \mathrm{~A}$ required to cause the collapse of $50 \%$ embryonic day 7 chick DRG growth cones (Luo et al., 1993). For collapse and branching assays, supernatant containing $0.5 \mathrm{CU}$ of Sema $3 \mathrm{~A}$, which corresponds to $\sim 75 \%$ collapse of growth cones from stage $35 / 36$ embryonic retina cultured for $24 \mathrm{hr}$, was applied to cultures. Values are presented as percentage collapse \pm SEM from a minimum of four independent experiments. A growth cone was classed as collapsed if it exhibited $\leq 2$ filopodia that were $<10 \mu \mathrm{m}$.

Growth cone turning and branching assays. Stable gradients of Sema 3A protein were formed as described (Lohof et al., 1992; de la Torre et al., 1997) by pulsatile ejection of Sema 3A or X-Sema 3A (1.9 CU) using a Picospritzer (General Valve). Briefly, the micropipette was positioned $100 \mu \mathrm{m}$ from the growth cone at $45^{\circ}$ to its direction of growth, and digital images were captured using a Quantix camera (Photometrics, Roper Scientific, Tucson, AZ) at 0 and $60 \mathrm{~min}$. Turning angles were measured using NIH Image software (National Institutes of Health, Bethesda, $\mathrm{MD}$ ), and statistical analysis was performed using the StatView software package (Abacus Concepts, Berkeley, CA).

Post-collapse branches typically emerged $10-40 \mu \mathrm{m}$ behind the growth cone and were $10-50 \mu \mathrm{m}$ in length. These were distinguished from filopodia, which typically emerged from the growth cone proper and were generally shorter $(\leq 10 \mu \mathrm{m})$. Branching was assayed by capturing images of neurites at $40 \times$ and measuring the distance from the tip of the neurite to the nearest branch point using IP Lab Spectrum P software (Scanalytics, Fairfax, VA).

Pharmacological agents. The following pharmacological reagents (Calbiochem, CN Biosciences) were bath applied to cultures $30 \mathrm{~min}$ before application of Sema $3 \mathrm{~A}$ in the collapse and turning assays (Song et al., 1998): $100 \mu \mathrm{M}$ (final concentration) GMP, 8-Bromo (8-BrcGMP), $10 \mu \mathrm{M}$ guanosine, 3', 5'-cyclic monophosphorothioate, 8-(4-cholorophenylthio)-, Rp-isomer (RpcGMPS), $20 \mu \mathrm{M}$ AMP, Sp-isomer (SpcAMPS) and $20 \mu \mathrm{M}$ AMP, Rp-isomer (RpcAMPS). For branching assays, the reagents were applied $10 \mathrm{~min}$ after the application of Sema $3 \mathrm{~A}$ or control supernatant.

Antibodies and immunohistochemistry. Retinal explant cultures were fixed for $1 \mathrm{hr}$ at $4^{\circ} \mathrm{C}$ in $2 \%$ paraformaldehyde containing $15 \%$ sucrose, washed three times in PBS, and blocked for $30 \mathrm{~min}$ in PBS plus $5 \%$ goat serum. Cultures were stained with the A5 anti-NP-1 and B2 anti-plexin antibodies (Takagi et al., 1987) (gifts from H. Fujisawa, Nagoya University, Japan) at 1:100 dilution for $2 \mathrm{hr}$ at room temperature. Anti-mouse Cy3-conjugated secondary antibody (Jackson Immunochemicals, Bar Harbor, ME) was used at a dilution of 1:1000 in PBS 5\% goat serum for $1 \mathrm{hr}$ at room temperature. Coverslips were mounted in Fluorosave (Calbiochem, CN Biosciences) + 2\% 1,4 diazabicyclo 2.2.2 octane (DABCO, Sigma). For NP-1 function-blocking experiments, stage 35/36 retinal explants were cultured for $24 \mathrm{hr}$ and preincubated with $20 \mu \mathrm{g} / \mathrm{ml}$ rabbit anti-NP-1 IgG (AN-1) (Pasterkamp et al., 1998), a gift from J. Verhaagen (The Netherlands Institute for Brain Research, Amsterdam, The Netherlands) or $20 \mu \mathrm{g} / \mathrm{ml}$ control antibody (rabbit IgG reagent grade; Sigma) before the application of Sema 3A. 9E10 anti-Myc (Sigma) was used at 1:1000 dilution and visualized with anti-mouse Cy3 as described above.

To obtain quantitative measurements of immunofluorescence, growth cones were randomly selected with phase optics at $40 \times$, and images were captured with a Quantix camera (Photometrics, Roper Scientific), and the outline was traced digitally using IP Lab Spectrum P Software (Scanalytics). A fluorescent image was then captured, and the amount of fluorescence within the area of the growth cone was calculated digitally. The level of background fluorescence in an adjacent area was similarly calculated and subtracted from the growth cone value to give a final intensity measurement (Hopker et al., 1999).

\section{RESULTS}

\section{Sema 3A causes rapid and transient collapse of Xenopus retinal growth cones}

Chick retinal growth cones do not collapse in response to Sema $3 \mathrm{~A}$ (Luo et al., 1993). This nonresponsiveness is likely attributable to the fact that chick retinal ganglion cells do not express NP-1 (Takagi et al., 1995). By contrast, NP-1 is expressed abundantly in Xenopus RGCs (Takagi et al., 1991; Fujisawa et al., 1995), raising the possibility that these neurons are sensitive to Sema 3A. To investigate this, we performed standard $1 \mathrm{hr}$ growth cone collapse assays (Raper and Kapfhammer, 1990) with supernatants from Sema 3A-transfected COS cells. Retinal growth cones from stage 


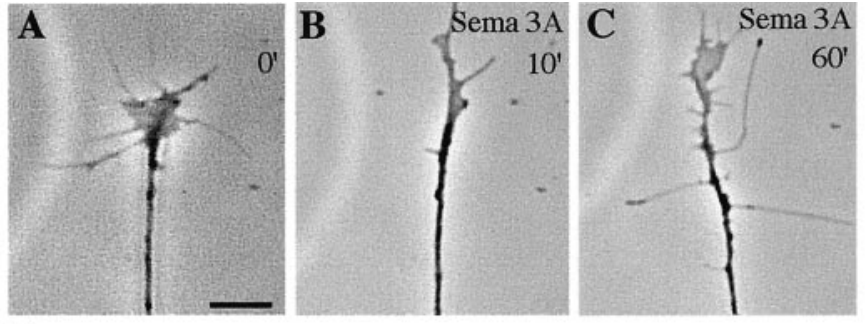

D

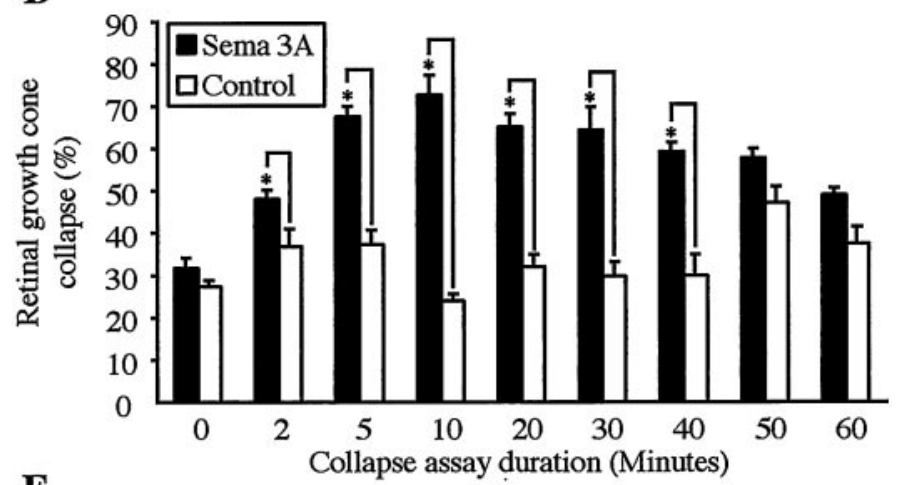

$\mathbf{E}$

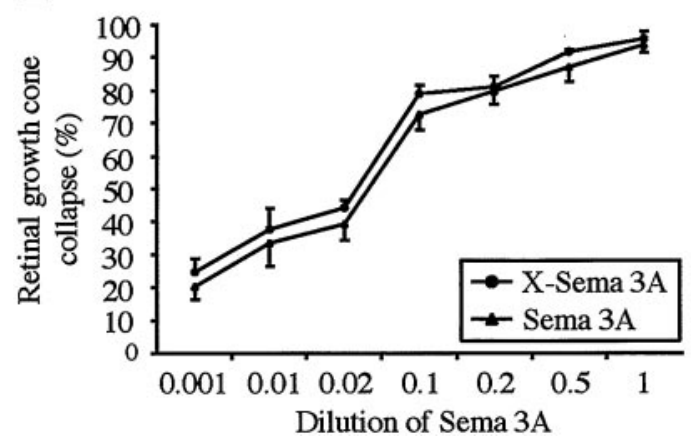

Figure 1. Sema 3A induces rapid and transient collapse of retinal growth cones. $A$, The morphology of a retinal growth cone before the bath application of Sema 3A; $B$, a collapsed retinal growth cone 10 min after Sema 3A application; $C$, recovery of the growth cone after $60 \mathrm{~min} . D$, Sema 3A induces the transient collapse of $24 \mathrm{hr}$ stage 35/36 growth cones. $E$, Sema $3 \mathrm{~A}$ and X-Sema $3 \mathrm{~A}$-induced collapse are dose dependent. ${ }^{*} p<$ 0.05; Mann-Whitney $U$ test. Scale bar (shown in $A$ ): $A-C, 10 \mu \mathrm{m}$.

35/36 explants (cultured for $24 \mathrm{hr}$ ) exhibited only a small amount of collapse after $60 \mathrm{~min}$ (15\% above control levels) (Fig. 1D). Casual inspection of Sema 3A-treated cultures after $10 \mathrm{~min}$, however, revealed unexpectedly high levels of collapse, leading us to examine the kinetics of the collapse response over a $1 \mathrm{hr}$ period (Fig. 1D). Collapse began just 2 min after Sema $3 \mathrm{~A}$ addition, rising to peak levels at $10 \mathrm{~min}(72 \%$ compared with $24 \%$,) and gradually declining thereafter. The amount of "background" collapse in control cultures was usually in the range of $25-40 \%$ and occasionally reached $50 \%$. An example of a growth cone showing rapid transient collapse in the presence of Sema 3A is shown in Figure $1 A-C$. All collapse experiments hereafter were assayed $10 \mathrm{~min}$ after the addition of Sema 3A. X-Sema 3A elicited essentially the same collapse-inducing activity as Sema $3 \mathrm{~A}$, and both induced collapse in a dose-dependent manner (Fig. 1E).

\section{Retinal growth cones gain Sema 3A responsiveness with age}

In retinal ganglion cells in vivo, NP-1 expression begins at stage 33/34, when leading RGC axons have just passed the optic chiasm, and gradually increases to maximum levels at stages 41-43 after the axons reach the optic tectum (Fujisawa et al., 1995). Therefore, the strong collapse response observed in stage 35/36 cultures is consistent with NP-1 mediating the response. If this is so, then retinal growth cones younger than stage 33/34 would be predicted to be insensitive to Sema $3 \mathrm{~A}$. To test this, retinal explants from different stage embryos (stages 24, 28, 35/36, and 37/38) were cultured for $24 \mathrm{hr}$ and then tested for collapse induced by Sema 3 A. Unexpectedly, growth cones from stages 24 and 28 explants exhibited collapse levels that were significantly higher than controls (56 vs $35 \%$ ), although stage $37 / 38$ growth cones exhibited still markedly higher levels $(76 \%)$ (Fig. $2 A)$. This indicates that either a receptor other than NP-1 is mediating the response of the young neurons or that NP-1 is being turned on during the $24 \mathrm{hr}$ period in culture.

To examine the latter possibility, stage 24 retinal explants were grown for varying time periods in culture $(6,24$, or $48 \mathrm{hr})$ and then assayed for collapse. A strongly age-dependent response to Sema 3A was observed (Fig. 2B). Stage 24 cultures aged for $6 \mathrm{hr}$ were insensitive to Sema $3 \mathrm{~A}$, showing almost no collapse, whereas those grown for 24 and $48 \mathrm{hr}$ exhibited moderate to high levels of collapse. This result is consistent with the idea that $6 \mathrm{hr}$ cultures do not express NP-1, whereas those aged for $24 \mathrm{hr}$ or more do express NP-1. To determine whether Sema 3A-induced collapse correlates with the presence of NP-1, stage 24 retinal explants were again cultured for 6,24 , or $48 \mathrm{hr}$ and immunostained for NP-1 using the A5 antibody (Takagi et al., 1987, 1991). The intensity of NP-1 staining in individual growth cones was quantified using digital capture of immunofluorescence. A strongly age-dependent increase in NP-1 expression was observed in growth cones of stage 24 explants (Fig. $2 C-F$ ). For example, 48 hr growth cones show a 10-fold higher fluorescence than $6 \mathrm{hr}$ growth cones, and intermediate levels occur at $24 \mathrm{hr}$ (Fig. $2 F$ ). To confirm that NP-1 expression correlates with the sensitivity to Sema 3A, growth cones from stages 24 and 35/36 were incubated with Sema 3A and stained for NP-1 (Fig. $2 K-P$ ). Young growth cones that are insensitive to Sema $3 \mathrm{~A}$ (6 hr, stage 24) did not express NP-1, whereas old growth cones (stage 35/36) that collapse in response to Sema $3 \mathrm{~A}$ showed strong positive NP-1 staining.

Antibodies raised against the ectodomain of NP-1 are able to inhibit in vitro responses to Sema 3A (He and Tessier-Lavigne, 1997; Kolodkin et al., 1997; Song et al., 1998). To test whether the responsiveness of Xenopus RGCs is dependent on NP-1 function, $24 \mathrm{hr}$ stage 35/36 retinal growth cones were preincubated with a function-blocking NP-1 antibody (AN-1) (Pasterkamp et al., 1998) $30 \mathrm{~min}$ before collapse assays were conducted. AN-1 treatment significantly reduced the amount of Sema 3A-induced collapse from $69 \%$ to control levels of $40 \%$ (Fig. $3 A$ ), confirming that the collapse response is most likely mediated by NP-1.

NP-1 requires plexin as a co-receptor to mediate its response to Sema 3A (Takahashi et al., 1999; Tamagnone et al., 1999; Rohm et al., 2000). Immunostaining with the B2 antibody against the single cloned Xenopus plexin shows that its expression follows a time course parallel to that of NP-1: absent in young growth cones, it appears at intermediate ages and rises to high levels in old growth cones (Fig. $2 G-J$ ). Although Xenopus plexin cannot be detected in young growth cones, we found that young growth cones were immunoreactive for plexin family members (data not shown) using the murine anti-plex 1 antibody (which recognizes plexins 1, 2, and 3) (Takahashi et al., 1999), indicating that other plexins are expressed early. Together, these observations suggest 


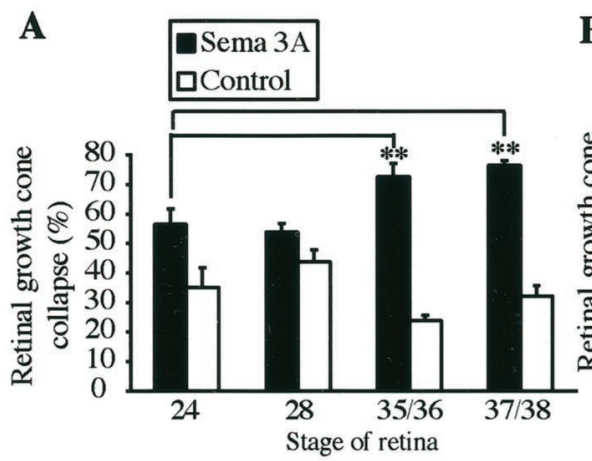

B
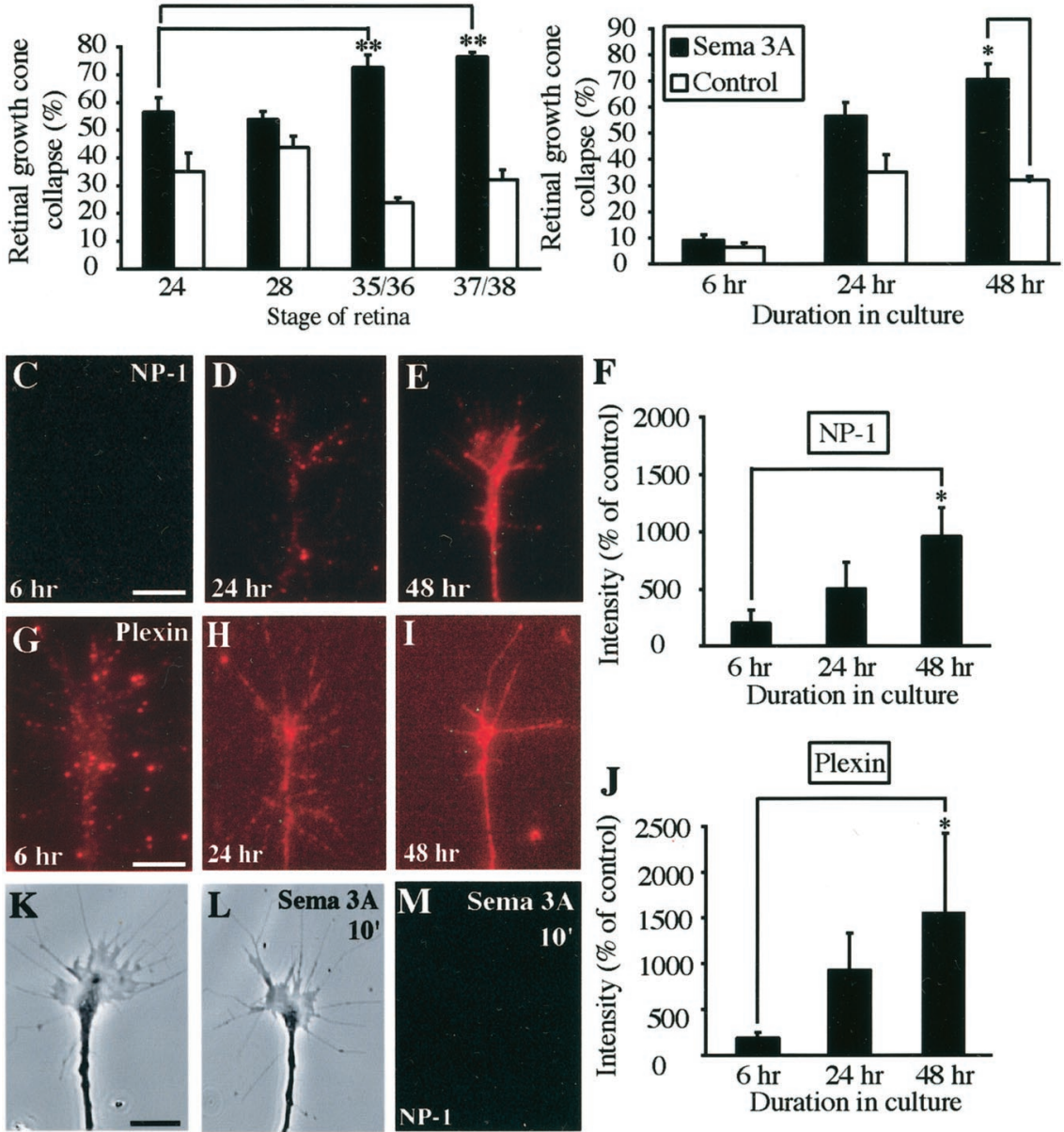

Duration in culture
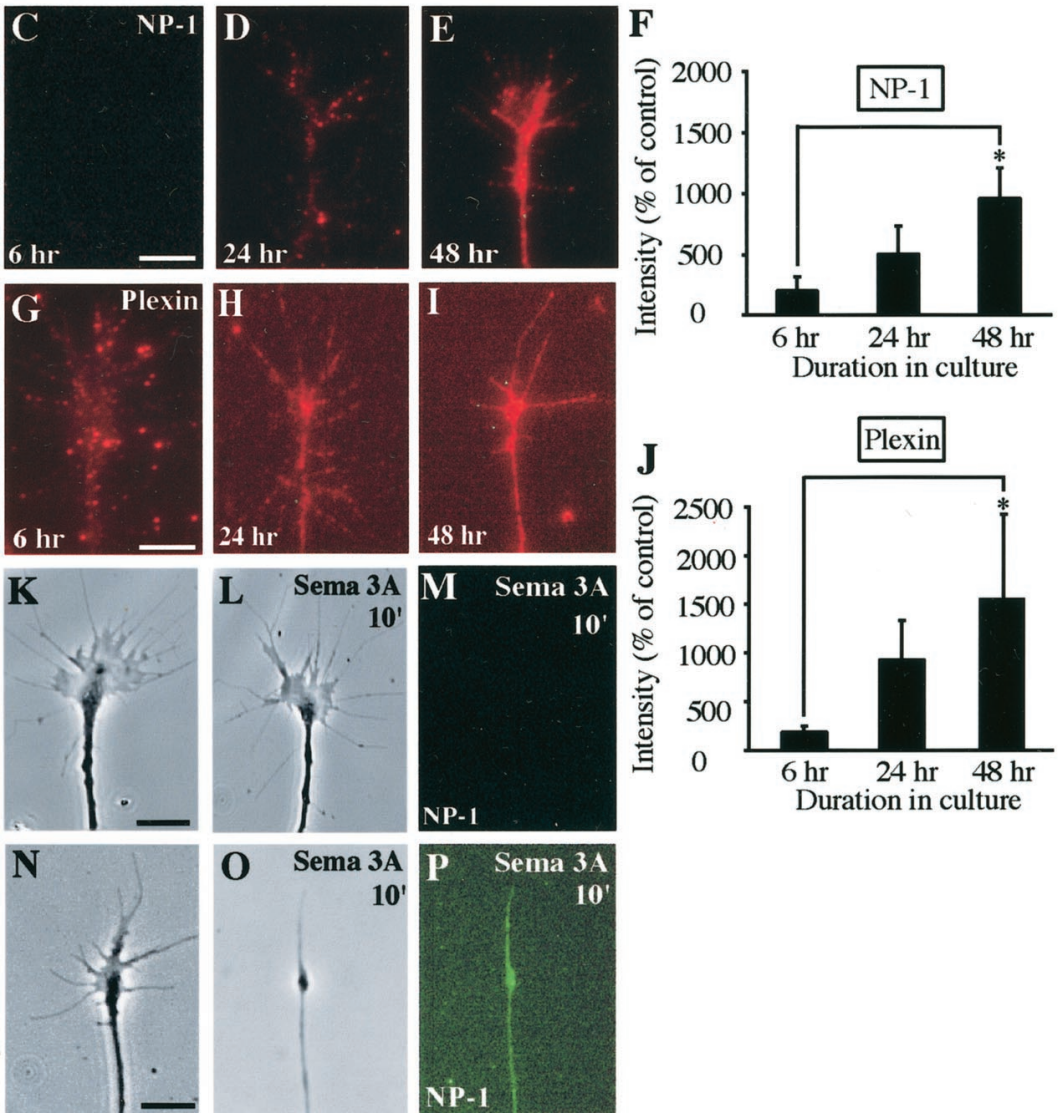

Figure 2. Retinal growth cones gain Sema $3 \mathrm{~A}$ responsiveness with age. $A$, Sema 3 A-induced collapse for $24 \mathrm{hr}$ stages $24,28,35 / 36$, and $37 / 38$ retinal growth cones. Stages $35 / 36$ and $37 / 38$ growth cones show significant increases in collapse compared with stages 24 and $28, * p<0.01$; ANOVA. $B$, Sema 3A-induced collapse for 6,24 , or $48 \mathrm{hr}$ stage 24 growth cones. Sema $3 \mathrm{~A}$-induced stage 24 growth cone collapse is significantly increased when cultured for $48 \mathrm{hr}$. ${ }^{*} p<0.05$; Mann-Whitney $U$ test. NP-1 and plexin expression increase in stage 24 plated retinal growth cones with duration in culture. Shown are representative photographs of NP-1 $(C-E)$ and plexin $(G-I)$ expression by growth cones using the A5 and B2 antibodies and a Cy3-conjugated secondary. Levels of NP-1 $(F)$ and plexin $(J)$ expression were quantified comparing percentage fluorescence intensity relative to control (without primary antibody). ${ }^{*} p<0.05$; Student's $t$ test $(C, G)$. Sema 3A-induced collapse correlates with NP-1 expression. A $6 \mathrm{hr}$ stage 24 growth cone $(K)$ does not collapse in response to the bath application of Sema 3A $(L)$ and does not express NP-1 $(M)$. A $24 \mathrm{hr}$ stage $35 / 36$ growth cone $(N)$ collapses in response to bath application of Sema $3 \mathrm{~A}(O)$ and expresses high levels of NP-1 $(P)$. that at the beginning of axonogenesis while axons are advancing through the proximal part of the retinotectal pathway, retinal growth cones lack NP-1/plexin and as a consequence are unresponsive to Sema 3A. As growth cones enter the more distal regions of the optic pathway, they start expressing NP-1/plexin and gain responsiveness to Sema $3 \mathrm{~A}$.

\section{Sema $3 A$ elicits repulsive turning in old retinal growth cones}

In collapse assays, growth cones experience a uniform concentration of Sema 3A that causes the entire growth cone to collapse. When collapsing factors such as Sema $3 \mathrm{~A}$ are presented as a point source or a gradient, growth cones exhibit local collapse and changes in the direction of growth, usually away from the Sema 3A source (Fan and Raper, 1995; Song et al., 1998). To test how retinal growth cones respond to a gradient of Sema $3 \mathrm{~A}$, we performed growth cone turning assays on older growth cones (Lohof et al., 1992; Zheng et al., 1994). The majority of growth cones tested turned away from Sema $3 \mathrm{~A}$ or X-Sema 3A-ejecting micropipettes (Fig. 4A-D), with an average negative angle of $-17^{\circ}$ and $-21^{\circ}$ compared with control angles of $\sim 0^{\circ}$ (Fig. $4 C-$ $E, H, I)$. In contrast, young growth cones (6 hr, stage 24$)$ showed no directional bias, with a mean turning angle close to $0^{\circ}$ (Fig. $4 F-I)$. This nonresponsiveness is not caused simply by an inability of young growth cones to turn, because similarly youthful growth cones exhibit strong turning responses to netrin-1 (data not shown).

\section{Precocious expression of NP-1 is sufficient to confer Sema $3 A$ sensitivity}

Young retinal growth cones neither express NP-1 nor respond to Sema $3 \mathrm{~A}$ in collapse and turning assays. If RGCs possess all the necessary components of the Sema 3A signal transduction pathway, then expression of NP-1 should be sufficient to confer them with Sema 3A sensitivity. Indeed, chick RGCs have been made responsive to Sema $3 \mathrm{~A}$ by virally mediated expression of NP-1 (Takahashi et al., 1998). To test whether the premature expression of NP-1 in stage 24 growth cones can elicit sensi- 
$\mathbf{A}$
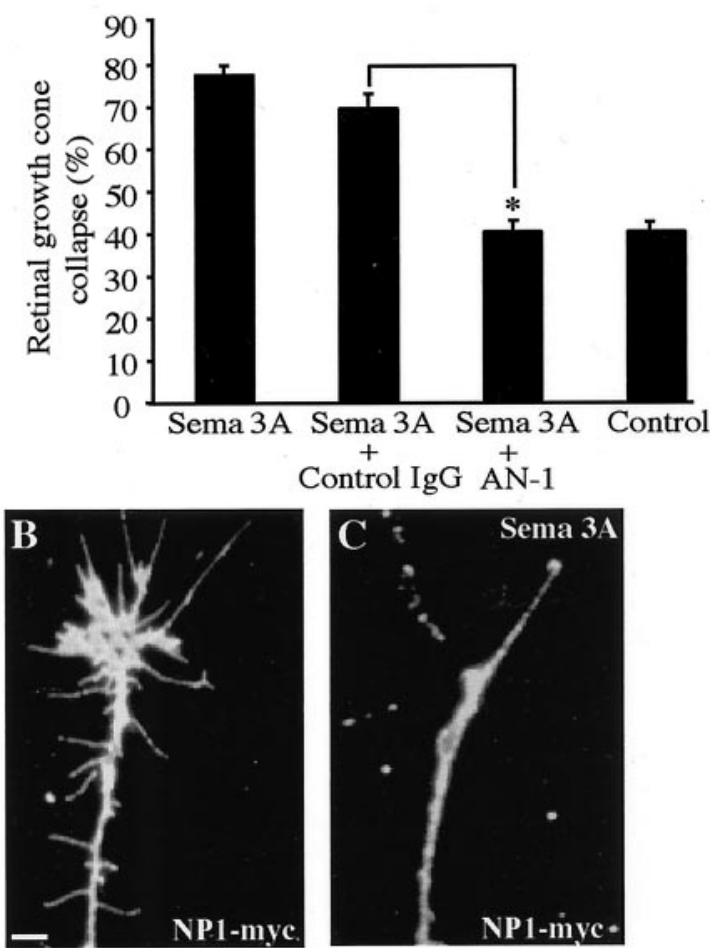

D

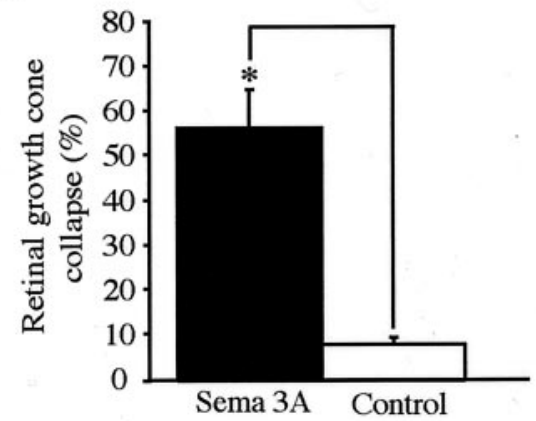

Figure 3. Precocious expression of NP-1 is sufficient to confer Sema 3A responsiveness on young retinal growth cones. $A$, The NP-1 antibody $(A N-1)$ inhibits Sema 3A-induced collapse. B, A 6 hr stage 24 retinal growth cone expressing NP-1-myc. $C$, A collapsed growth cone expressing NP-1-myc in the presence of Sema 3A. Scale bar, $10 \mu \mathrm{m}$. D. Sema 3A induces the collapse of $6 \mathrm{hr}$ stage 24 retinal growth cones expressing NP-1-myc. ${ }^{*} p<0.05$; Mann-Whitney $U$ test.

tivity to Sema 3A, full-length myc-tagged Xenopus NP-1 was expressed by mRNA blastomere injection. NP-1 mRNA was typically coinjected with GFP-RNA to enable embryos with GFP-expressing eyes to be preselected for culture, thereby increasing the likelihood of obtaining NP-1-expressing neurites. NP-1-myc-expressing growth cones exhibit significant collapse (56\% compared with control, 7\%) (Fig. 3B-D). This shows that growth cones from retinal explants plated from stage 24 embryos possess all the other molecular components necessary for Sema $3 \mathrm{~A}$ to elicit growth cone collapse and lack only NP-1. Because Xenopus plexin is not expressed at this early time, one of the other plexin members detected with the anti-plex 1 antibody probably interacts with the ectopic NP-1 to form a functional complex.

\section{Sema 3A promotes branching of growth cones after recovery from collapse}

The surprisingly transient nature of Sema 3A-induced Xenopus retinal growth cone collapse prompted us to investigate further the process of growth cone recovery. We noticed that at the end of $1 \mathrm{hr}$ exposure to Sema 3A, many growth cones had elaborated multiple side branches or had bifurcated (Figs. $1 C, 5 D$ ), suggesting that recovery from collapse might be accompanied by branching. Indeed, quantitation showed that growth cones treated with $0.5 \mathrm{CU}$ of Sema 3A or X-Sema 3A for $1 \mathrm{hr}$ exhibited markedly higher frequencies of branching (31 and $41 \%$, respectively) than those treated with control supernatant (10\%) (Fig. 5E). Branching correlated with the amount of Sema 3A applied, because $1.9 \mathrm{CU}$ of Sema 3A resulted in 55\% branching. Because the average rate of growth is $\sim 35 \mu \mathrm{m} / \mathrm{hr}$ in both control and Sema 3A-treated conditions (data not shown), then most of the branching must occur within the axon tip that extended in the presence of Sema 3A during the experimental period. The trend is demonstrated in Figure $5 F$, which shows the probability of branching within the distal-most $100 \mu \mathrm{m}$ of neurite growth; most of the increase in branching is seen within the first $40 \mu \mathrm{m}$ compared with the last $60 \mu \mathrm{m}$.

\section{Pharmacological perturbation of cGMP signaling modulates the collapse, turning, and branching responses to Sema $3 A$}

Sema 3A-induced growth cone collapse has been shown to be inhibited by bath application of 8 -BrcGMP, a membranepermeable agonist of protein kinase $\mathrm{G}(\mathrm{PKG})$. This has also been shown to convert a repulsive response to Sema $3 \mathrm{~A}$ into an attractive one in the growth cone turning assay. To investigate whether cGMP plays a role in the behavior of Xenopus retinal growth cones, pharmacological agents were applied to $24 \mathrm{hr}$ stage $35 / 36$ retinal growth cones for a minimum of $30 \mathrm{~min}$ before the collapse assay with Sema 3A. Application of Sema 3A in the presence of $100 \mu \mathrm{M} 8$-BrcGMP or $10 \mu \mathrm{M}$ RpcGMPS (agonists and antagonists, respectively, of PKG) resulted in a significantly reduced level of growth cone collapse ( 24 and $46 \%$, respectively) compared with Sema 3A alone (73\%) (Fig. 6A). In contrast, application of $20 \mu \mathrm{M}$ SpcAMPS or $20 \mu \mathrm{M}$ RpCAMPS, agonists and antagonists of protein kinase A, respectively, at concentrations known to be sufficient to modulate netrin-1-mediated growth cone turning responses (Ming et al., 1997), did not significantly alter the amount of growth cone collapse (Fig. 6A) Increasing concentrations of SpcAMPS and RpcAMPS up to 1 $\mathrm{mm}$ did not significantly affect the level of Sema 3A-induced retinal growth cone collapse (data not shown).

To investigate the effects on turning, reagents were added $30 \mathrm{~min}$ before the placement of the pipette. The presence of $100 \mu \mathrm{M}$ 8 -BrcGMP in the medium of stage 32 retinal growth cones caused growth cones to turn toward the Sema 3A-ejecting pipette, thus converting a repulsive response to Sema $3 \mathrm{~A}$ into an attractive one (mean turning angle $+16^{\circ}$ ) (Fig. 6B). Application of $10 \mu \mathrm{M}$ RpcGMPS caused a significant reduction in the amount of Sema3Ainduced growth cone repulsion (mean turning angle $-6^{\circ}$ ) and resulted in a heterogeneous mix of positive and negative turning responses (Fig. $6 C$ ). In contrast, application of $20 \mu \mathrm{M}$ SpCAMPS or $20 \mu \mathrm{M}$ RpcAMPS did not alter Sema 3A-induced growth cone repulsion (mean turning angles $-12^{\circ}$ and $-20^{\circ}$ ) (Fig. $6 D-F$ ).

Because both the collapse and turning responses to Sema $3 \mathrm{~A}$ can be modulated by pharmacological perturbation of the intracellular cGMP signaling pathway, we next asked whether the branching response could also be modified in a similar manner. 

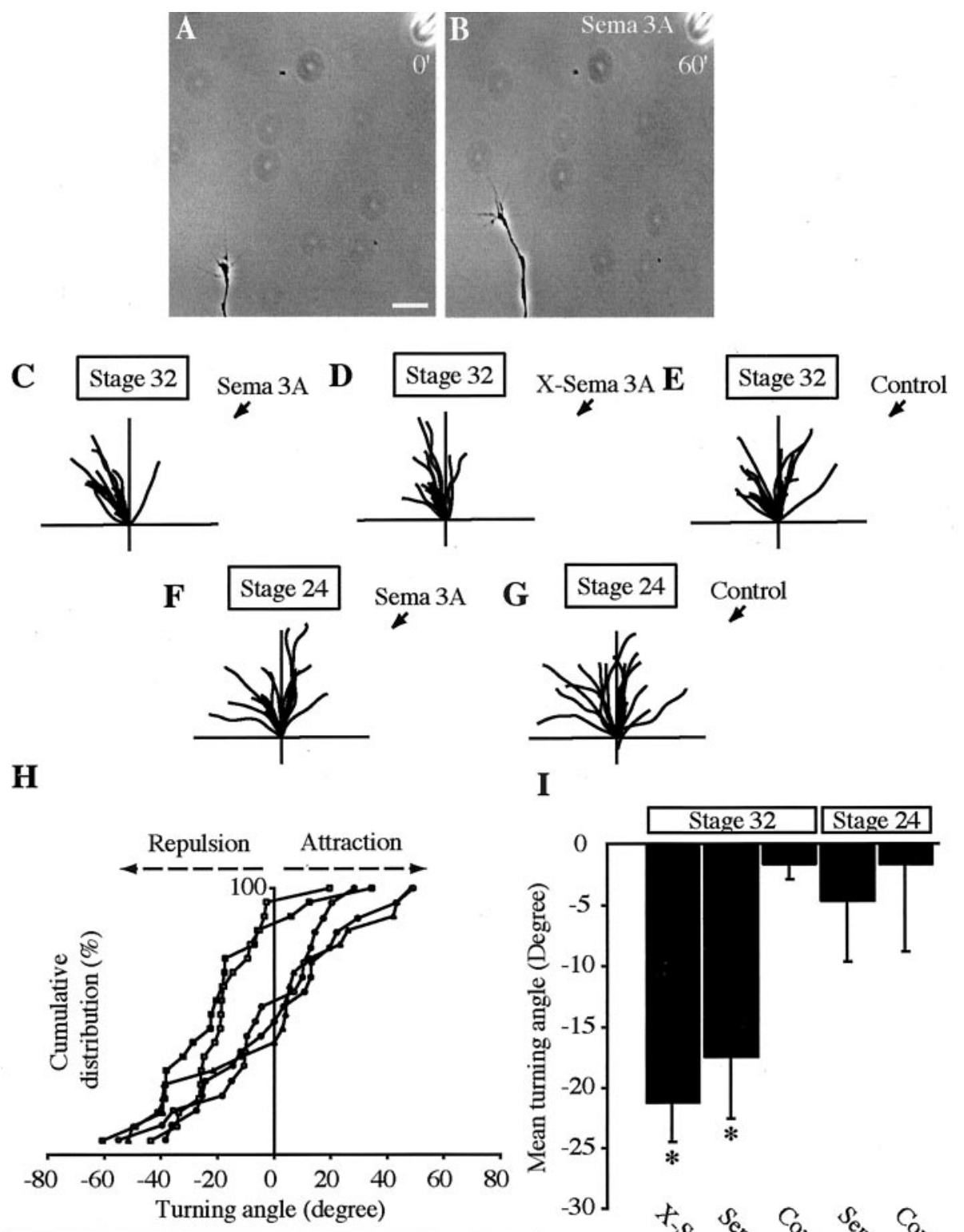

I

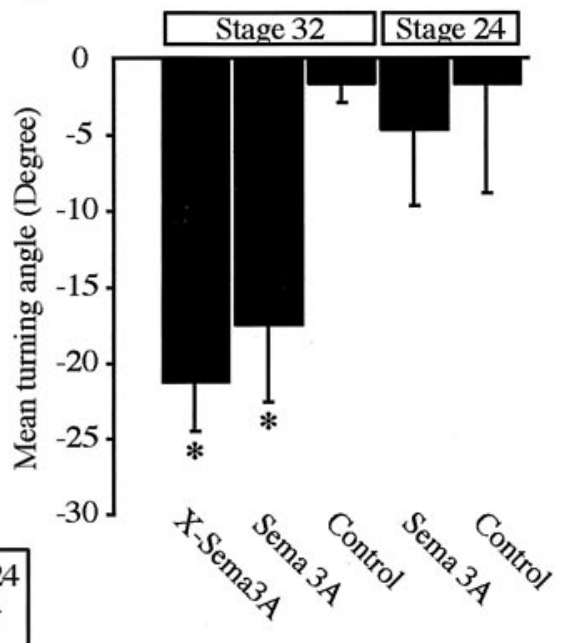

Figure 4. Sema 3A elicits repulsive turning in old retinal growth cones. $A$, A $16-26 \mathrm{hr}$ stage 32 retinal growth cone before being exposed to a gradient of Sema 3A. Scale bar, $10 \mu \mathrm{m}$. B, After $60 \mathrm{~min}$ the growth cone is repelled by a gradient of Sema 3A. Traces depict the trajectories of 16-26 hr stage 32 neurites in the presence of a Sema 3A gradient applied at the black arrow $(C)$ or X-Sema 3A gradient $(D)$ compared with a gradient of control supernatant (Control, E). Traces depict the trajectories of 6-12 hr stage 24 retinal neurites in the presence of a gradient of Sema 3A that does not induce repulsive turning $(F)$ and control $(G) . H$, Cumulative frequency graph showing the distribution of turning angles for stages 32 and 24 retinal growth cones, Sema $3 \mathrm{~A}$, and control. Sema $3 \mathrm{~A}$ and $\mathrm{X}$-Sema $3 \mathrm{~A}$ are repulsive to growth cones from stage 32 plated retinal explants; i.e., most of the turning angles are negative relative to control turning angles and the turning angles for a gradient of Sema $3 \mathrm{~A}$ on stage 24 growth cones and control. I, Mean turning, Sema 3A, and X-Sema 3A induce significant repulsion of stage 32 retinal growth cones. ${ }^{*} p<0.05$; Kolmogorov-Smirnov test.
Indeed, $100 \mu \mathrm{M}$ 8-BrcGMP or $10 \mu \mathrm{M}$ RpcGMPS added $10 \mathrm{~min}$ after Sema 3A significantly reduced Sema 3A-induced branching from $30 \%$ to 17 and $11 \%$, respectively (Fig. $6 G$ ). To test whether the decrease in branching observed was caused by an inhibition of neurite growth, we measured mean neurite lengths in the presence of Sema 3A and $100 \mu \mathrm{M}$ 8-BrcGMP or $10 \mu \mathrm{M}$ RpcGMPS. These were not significantly different from Sema $3 \mathrm{~A}$ and control supernatant alone (data not shown). Reagents that perturb protein kinase A signaling (SpcAMPS, RpcAMPS) did not effect branching or the rate of neurite extension over 1 hr (Fig. 6G) (data not shown). Our results indicate that Sema 3A-induced branching, like collapse and turning, are modulated by the cGMP second messenger pathway.

\section{Sema $3 A$ expression in and around the developing optic pathway}

To begin to examine the role of Sema $3 \mathrm{~A}$ in retinal axon growth in vivo, a homolog of Sema $3 \mathrm{~A}$ was cloned and its expression pattern was analyzed in and around the developing optic pathway. In situ hybridization in conjunction with anterograde HRP labeling of RGC axons revealed that X-Sema $3 \mathrm{~A}$ is absent from the optic tract and the chiasm regions of the pathway (Fig. $7 A-C$ ). At stage 33/34, when the leading RGC axons are in the mid-optic tract (Holt, 1984), Sema 3A is highly expressed in the telencephalon in a region that closely abuts $(\sim 20 \mu \mathrm{m})$ the anterior border of the mid-diencephalon where the optic tract makes a $45^{\circ}$ bend posteriorly. X-Sema $3 \mathrm{~A}$ is also highly expressed in the posterior part of the optic tectum (Fig. $7 A, B$ ). At stage 33/34, X-Sema3A is restricted to the most posterior region and spreads into the ventral tectum by stage 41 . The retinal terminals and X-Sema 3A seem to occupy exclusive, nonoverlapping territories in the tectum, with the terminals being located in the anterior half and $\mathrm{X}$-Sema 3A in the posterior and ventral parts (Fig. 7D). Horizontal sections show that X-Sema 3A transcripts are located deep in the medulla and the telencephalon close to the ventricle but 


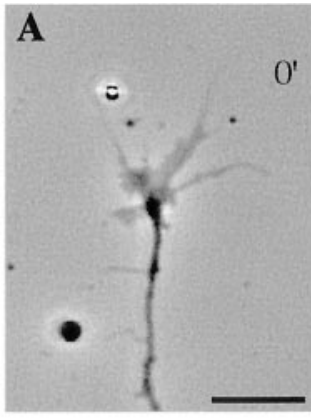

$\mathbf{E}$

Figure 5. Sema 3A elicits branching after recovery from collapse. $A$, A $24 \mathrm{hr}$ stage 35/36 retinal growth cone before the application of Sema 3A. B, The same growth exhibiting collapsed morphology after $10 \mathrm{~min}$. $C$, After $30 \mathrm{~min}$ the growth cone has begun to branch. $D$, After 60 min the branch remains. Scale bar, 10 $\mu \mathrm{m}$. E, Sema 3A induces the branching of retinal growth cones. Cumulative branching in the most distal $100 \mu \mathrm{m}$ of neurite growth illustrates that the majority of the branching occurs within approximately the first $35 \mu \mathrm{m}$, the mean neurite growth in $1 \mathrm{hr} .{ }^{*} p<0.05$; Mann-Whitney $U$ test.
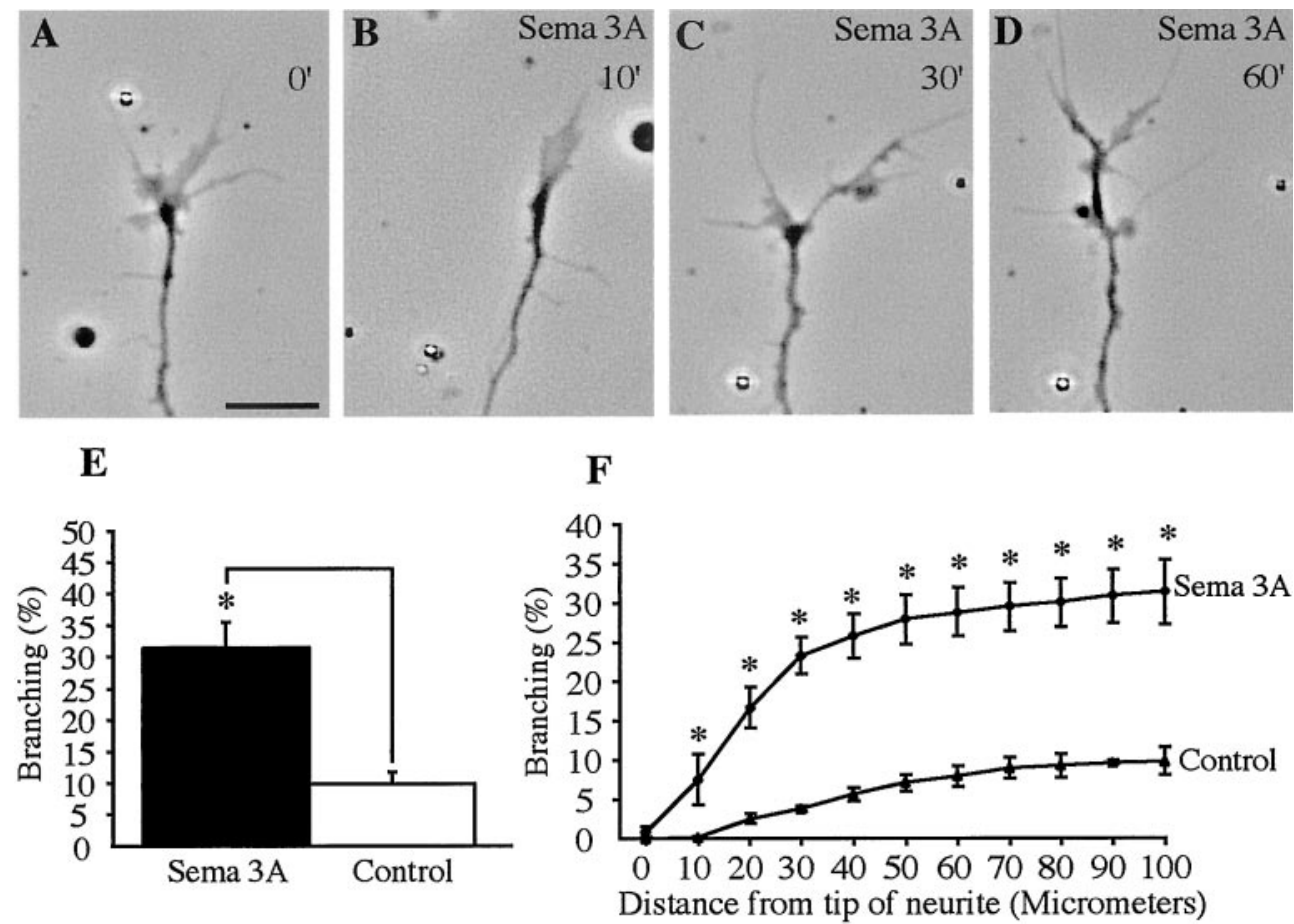

superficially in the tectum. The superficially located retinal terminals lie adjacent to the $\mathrm{X}$-Sema 3A-expressing region (Fig. $7 E, F)$.

\section{DISCUSSION}

Repulsive guidance molecules such as Sema 3A have been identified as a class of cues involved in guiding axon growth (Kolodkin, 1996; Tessier-Lavigne and Goodman, 1996). Sema 3A has been shown to act as a repulsive guidance cue for sensory and motor axons (Messersmith et al., 1995; Puschel et al., 1995; Varela-Echavarria et al., 1997) but not RGC axons. Here we show for the first time that Sema $3 \mathrm{~A}$ can act as a repulsive signal for retinal growth cones and that it elicits three different types of behavior in vitro: collapse, repulsive turning, and terminal branching. Each behavior is sensitive to pharmacological perturbation of cGMP, but not cAMP, suggesting that all three Sema $3 \mathrm{~A}$-induced changes are mediated through the same second messenger pathway. We also show that the Sema 3 A receptor components, NP-1 and plexin, are developmentally regulated and not expressed until axons reach the optic tract. This late switch-on of expression occurs even when explants are aged in culture, excluding the possibility that a retrograde signal from a pathway cue triggers the changes. This suggests that an intrinsic clock mechanism may exist in these neurons to regulate the sensitivity of growth cones to particular guidance cues.

When RGC axons reach the tectum, a time when they express high levels of NP-1 (Fujisawa et al., 1995), Sema 3A is expressed strongly in the posterior tectum, suggesting that X-Sema 3A plays a role in the termination of axon growth. Sema $3 \mathrm{~A}$ has been shown to regulate target invasion in the developing chick olfactory system (Renzi et al., 2001). It is expressed in the telencephalon when olfactory axons first arrive and is downregulated coincident with a period of invasion of the target. Olfactory axons expressing dominant negative NP-1 enter the target prematurely, suggesting that the primary function of Sema 3As is to keep axons waiting until the target is ready to receive them. In the
Xenopus visual system, Sema 3A may play a similar role, keeping axons out of the immature posterior tectum where cells are proliferating and not ready to receive input. There is a steep anterior-posterior gradient of differentiation in the Xenopus tectum, with the anterior tectal cells differentiating first. The posterior tectum continues to proliferate and generate new tectal cells throughout life (Straznicky and Gaze, 1972). A critical test of the role of NP-1 in axon growth, of course, would be to block its function in vivo. Our attempts to express a dominant negative form of NP-1 in retinal ganglion cells, however, were not successful. Lipofection and mRNA injection of the dominant negative NP-1 construct used by Raper and colleagues (Renzi et al., 2001) to block NP-1 function in olfactory neurons yielded extremely poor expression in retinal neurons, and of the few positive cells found in the RGC layer, most lacked axons and dendrites (data not shown). Furthermore, in culture, growth cones expressing the dominant negative NP-1 collapsed in response to Sema 3A (data not shown). Further attempts to inhibit NP-1 function in vivo applying anti-NP-1 antibodies or a soluble form of NP-1 to an exposed brain preparation resulted in inconsistent defects in axon path finding (data not shown).

Axon branching is an important process in the formation of synaptic connections (for review, see Acebes and Ferrus, 2000). Branches can form by collateral branch formation (Heffner et al., 1990; Kalil et al., 2000) or by the terminal arborization of the primary growth cones, as has been observed in time-lapse studies of Xenopus RGCs on entering the tectum (Harris et al., 1987). Target-derived molecules have been implicated particularly in the formation of collateral branches (Heffner et al., 1990). More recently, ephrin A5 and slit proteins, previously identified as axon repellents, have been implicated in branching (Castellani et al., 1998; Wang et al., 1999), suggesting a link between axon repulsion and axon branching (Brose and Tessier-Lavigne, 2000). In contrast to the previously identified role of Sema $3 \mathrm{~A}$ as an inhibitor of branching in the mammalian cortex (Bagnard et al., 1998), the 
$\mathbf{A}$

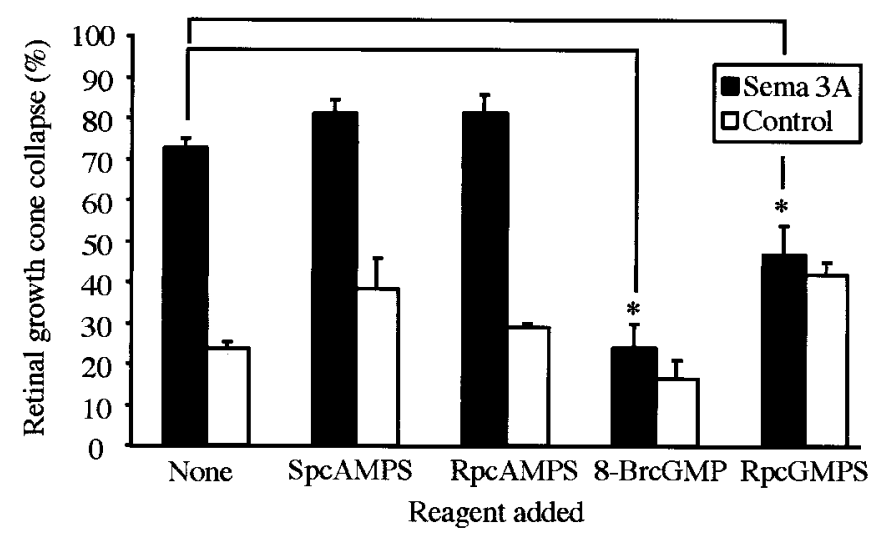

B

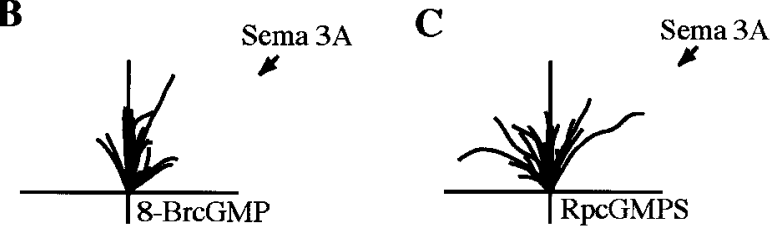

D

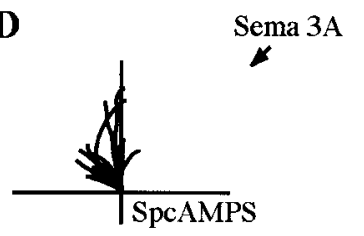

$\mathbf{E}$

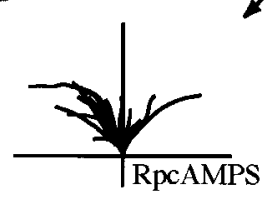

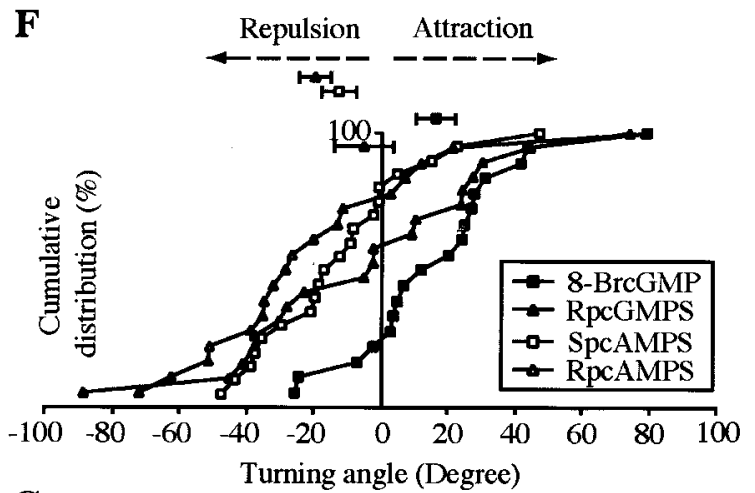

G

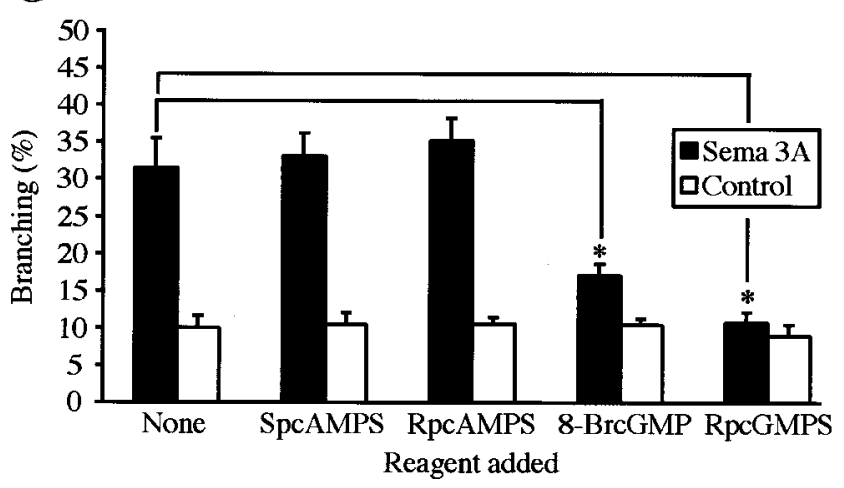

Figure 6. Pharmacological perturbation of cGMP signaling modulates the responses to Sema 3A. Pharmacological perturbation of cGMP signaling but not cAMP signaling via the activation or inhibition of protein kinase G significantly reduces $24 \mathrm{hr}$ stage 35/36 Sema 3A-induced growth cone collapse $(A)$. ${ }^{*} p<0.05$; Mann-Whitney $U$ test. Traces depict the trajectories of $16-26 \mathrm{hr}$ stage 32 retinal neurites in the presence of observation that Xenopus RGCs undergo branching during recovery from collapse supports such a role for X-Sema 3A. Immediately after entering the anterior tectum, the RGC axons slow down and lose their expanded growth cones, and terminal arbors form by a process of back-branching behind the leading tip (Harris et al., 1987). Given that Sema 3A causes collapse and branching in vitro, we hypothesize that in addition to prohibiting growth into the posterior tectum, Sema 3A may play a role in terminal branching. However, one difference in culture is that in addition to back-branching, growth cone bifurcation occurs, a process that is rare in vivo. This may represent a limitation of the two-dimensional culture system. Alternatively, the observed branching may represent a general response that follows collapse induced by repulsive cues (Davenport et al., 1999). It is likely that the complexity of branching is mediated by a combinatorial effect of multiple molecules in addition to Sema 3A. For example, BDNF promotes the branching of Xenopus RGC axons in the tectum (Cohen-Cory and Fraser, 1995), and neurotrophins have been shown to rapidly modulate responses to Sema 3A (Tuttle and O'Leary, 1998).

The chick tectum does not express Sema 3A (Luo et al., 1993), nor do chick RGCs express high levels of NP-1 (Takagi et al., 1995), but it does express the highly related semaphorin, Sema 3D (collapsin-2) (Luo et al., 1995), despite RGCs lacking expression of semaphorin receptors. Chick RGCs can be made responsive to Sema $3 \mathrm{~A}$ by ectopic expression of NP-1, demonstrating that these cells possess the downstream signaling effectors needed to transduce Sema 3A (Takahashi et al., 1998). Sema 3D (Halloran et al., 1999) and Sema 3A1 (Yee et al., 1999) are expressed in the zebrafish tectum, indicating that considerable evolutionary divergence has occurred in the vertebrate visual system.

Growth cones are able to change their responsiveness to guidance cues depending on their environmental experience or age in development. For example, commissural axons lose their responsiveness to netrin-1 after experiencing the floor plate, a rich source of netrin-1 (Shirasaki et al., 1998). Xenopus retinal growth cones undergo an age-dependent decrease in their ability to respond attractively to netrin- 1 that is independent of the previous experience of the growth cone to netrin-1 or to their pathway environment (D. A. Shewan, A. Dwivedy, R. B. Anderson, and C. E. Holt, unpublished observations). Our in vitro observations suggest that the gain of responsiveness to Sema $3 \mathrm{~A}$ in the collapse assay over time in culture is also regulated intrinsically and is correlated with the developmental upregulation of NP-1 and plexin. The parallel acquisition of growth cone responsiveness to Sema $3 \mathrm{~A}$ in culture and in vivo indicates that experience of the proximal part of the pathway (optic nerve and midline chiasm) is not required for the onset of expression of NP-1. This is in

\footnotetext{
$\leftarrow$

pharmacological modulators of cGMP and cAMP signaling $(B-E)$ in the medium and a directional source of Sema 3A. B, The activation of PKG with $100 \mu \mathrm{M} 8$-BrcGMP converts Sema 3A-induced repulsion to attraction. $p<0.01$; Kolmogorov-Smirnov test. $C$, Inhibition of PKG with $10 \mu \mathrm{M}$ RpcGMPS abolishes Sema 3A-induced repulsion, leading to a heterogeneous turning response. $D, E$, Activation or inhibition of PKA with $20 \mu \mathrm{M}$ SpcAMPS or RpAMPS does not significantly affect Sema 3A-induced repulsion. $F$, Cumulative frequency graph showing the turning angles to Sema 3A. In the presence of $100 \mu \mathrm{m} 8$-BrcGMP, the curve is shifted to the right. With $10 \mu \mathrm{M}$ RpcGMPS, approximately equal numbers of angles lie on either side, and with $20 \mu \mathrm{M}$ SpcAMPS or RpcAMPS, most turning angles lie to the left, indicating repulsion. $G$, Activation or inhibition of PKG inhibits Sema 3A-induced branching. ${ }^{*} p<0.05$; Mann-Whitney $U$ test.
} 

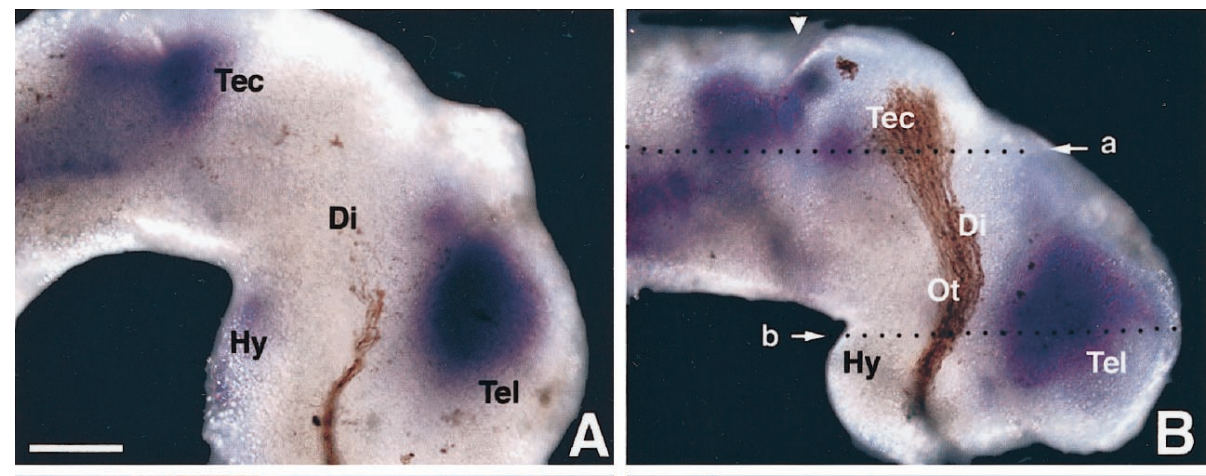

Figure 7. Sema 3A expression in the developing optic pathway. Shown are whole-mount lateral views of stage $33 / 34(A)$ and stage $41(B-D)$ Xenopus brains in which the RGCs have been anterogradely filled with HRP and visualized with DAB. Sema $3 \mathrm{~A}$ is highly expressed in the telencephalon, hindbrain, and posterior tectum but not in the optic tract $(A, B)$. Shown is magnified view of Sema $3 \mathrm{~A}$ expression in the diencephalon $(C)$ and posterior tectum $(D)$ illustrating its proximity to the RGC axons. Shown are horizontal paraffin sections at the level of the tectum $(E)$ and telencephalon $(F)$. The level of the sections in $E$ and $F$ is denoted by the white arrow in $B$, labeled $a$ and $b$, respectively. $D i$, Diencephalon; $H b$, hindbrain; $H y$, hypothalamus; Ot, optic tract; Tec, tectum; Tel, telencephalon. White arrowheads indicate the midbrain/hindbrain boundary. Black arrowheads highlight the HRP-filled RGC axons. Scale bar (shown in $A$ ): $A, B, E, F, 100 \mu \mathrm{m} ; C, D, 50 \mu \mathrm{m}$. Anterior is to the right.
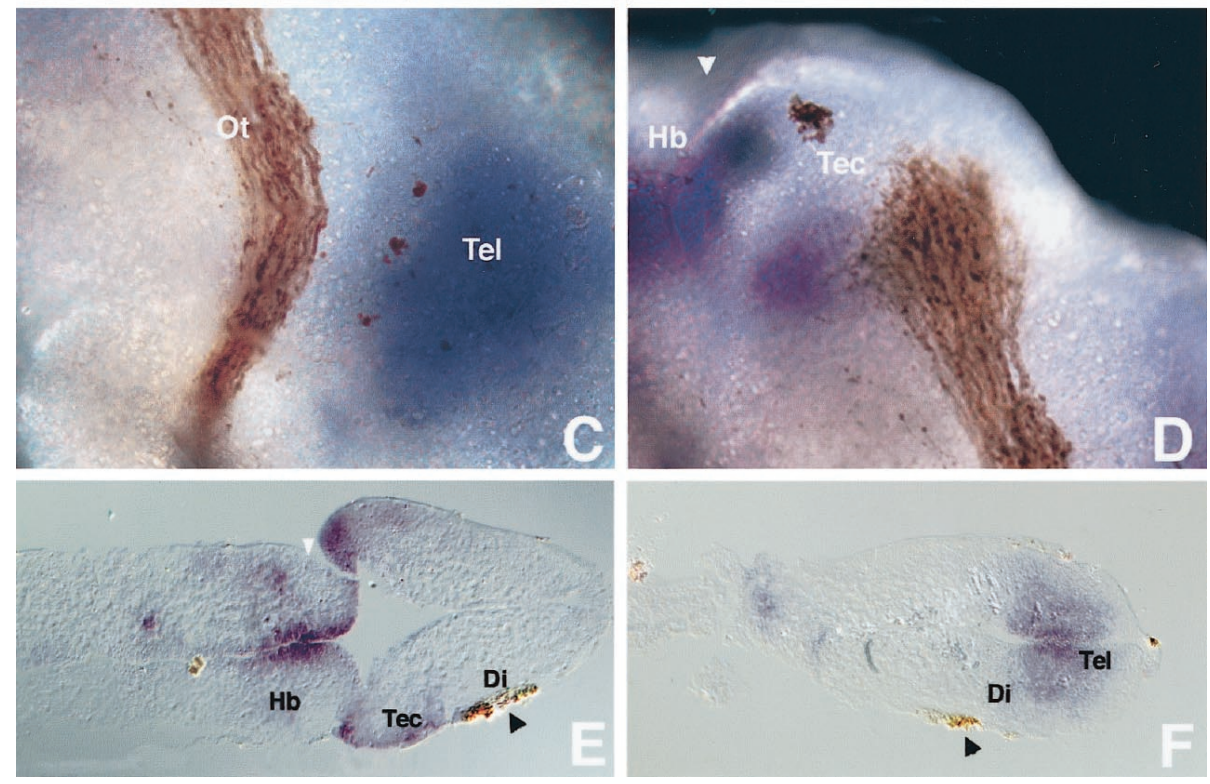

contrast to commissural axons, which acquire responsiveness to the midline repellent Slit and semaphorins as a result of crossing the floor plate (Zou et al., 2000). Thus, our results suggest that one novel mechanism of the regulation of growth cone guidance is by intrinsic temporal control of expression of receptors to a specific guidance cue at the cell surface.

Using cultured Xenopus spinal neurons, Poo and colleagues (Song et al., 1998) showed that the Sema 3A-induced collapse and turning responses can be modulated by pharmacological perturbation of the intracellular cGMP but not the cAMP signaling pathway. Increasing cGMP signaling by activation of PKG inhibited growth cone collapse and converted a repulsive turning response into an attractive one. In this study we report similar effects in Xenopus retinal growth cones. We extend these findings by showing that RpcGMPS, an inhibitor of PKG, blocks the collapse and branching responses, and in contrast to Xenopus spinal neurons (Song et al., 1998), neutralized Sema 3A-induced repulsive turning. These pharmacological perturbation studies indicate that activation or inhibition of PKG changes the responses to Sema $3 \mathrm{~A}$ and suggest that there is an optimum level of $\mathrm{PKG}$ activity required for Sema $3 \mathrm{~A}$ to elicit growth cone collapse, repulsive turning, and branching. The results obtained using an agonist and antagonist of cGMP signaling are similar to those observed by Polleux et al. (2000), who have suggested that in the case of cortical dendrite outgrowth, cGMP signaling is not acting as a simple "polarity switch" controlling the decision between attraction and repulsion. The intracellular mediators of branching and arborization are almost completely unknown. The present study provides the first evidence that cGMP signaling modulates neurite branching in response to a specific stimulus, implicating the involvement of cGMP in branch formation. Because cAMP has been shown to promote branching (Weeks et al., 1991), branching is likely under the control of multiple intracellular signaling pathways converging on common mediators of the cytoskeleton.

In addition to inducing transient collapse and branching, Sema $3 \mathrm{~A}$ can act as a directional guidance cue in the growth cone turning assay for retinal growth cones. This is consistent with previous studies showing that Sema $3 \mathrm{~A}$ elicits the repulsive turning of Xenopus spinal growth cones (Song et al., 1998) and chick DRGs when presented as a localized source (Fan and Raper, 1995). Strong expression of X-Sema 3A was seen in the telencephalon closely abutting the border of the mid-diencephalon where the optic tract bends $45^{\circ}$ caudally. It is tempting to speculate that X-Sema $3 \mathrm{~A}$ plays a role in reorienting the growth of retinal axons caudally toward the tectum at this bend-point. Further work will be necessary to test this idea and to determine the exact role of Sema $3 \mathrm{~A} / \mathrm{NP}-1$ interactions in regulating the behavior of retinal axons in vivo.

\section{REFERENCES}

Acebes A, Ferrus A (2000) Cellular and molecular features of axon collaterals and dendrites. Trends Neurosci 23:557-565.

Bagnard D, Lohrum M, Uziel D, Puschel AW, Bolz J (1998) Semaphorins act as attractive and repulsive guidance signals during the development of cortical projections. Development 125:5043-5053.

Brose K, Tessier-Lavigne M (2000) Slit proteins: key regulators of axon guidance, axonal branching, and cell migration. Curr Opin Neurobiol 10:95-102. 
Castellani V, Yue Y, Gao PP, Zhou R, Bolz J (1998) Dual action of a ligand for Eph receptor tyrosine kinases on specific populations of axons during the development of cortical circuits. J Neurosci 18:4663-4672.

Chien CB, Harris WA (1994) Axonal guidance from retina to tectum in embryonic Xenopus. Curr Top Dev Biol 29:135-169.

Cohen-Cory S, Fraser SE (1995) Effects of brain-derived neurotrophic factor on optic axon branching and remodelling in vivo. Nature 378:192-196.

Cornel E, Holt C (1992) Precocious pathfinding: retinal axons can navigate in an axonless brain. Neuron 9:1001-1011.

Davenport RW, Thies E, Cohen ML (1999) Neuronal growth cone collapse triggers lateral extensions along trailing axons. Nat Neurosci $2: 254-259$.

de la Torre JR, Hopker VH, Ming GL, Poo MM, Tessier-Lavigne M, Hemmati-Brivanlou A, Holt CE (1997) Turning of retinal growth cones in a netrin-1 gradient mediated by the netrin receptor DCC. Neuron 19:1211-1224.

Dingwell KS, Holt CE, Harris WA (2000) The multiple decisions made by growth cones of RGCs as they navigate from the retina to the tectum in Xenopus embryos. J Neurobiol 44:246-259.

Fan J, Raper JA (1995) Localized collapsing cues can steer growth cones without inducing their full collapse. Neuron 14:263-274.

Fujisawa H, Takagi S, Hirata T (1995) Growth-associated expression of a membrane protein, neuropilin, in Xenopus optic nerve fibers. Dev Neurosci 17:343-349.

Halloran MC, Severance SM, Yee CS, Gemza DL, Raper JA, Kuwada JY (1999) Analysis of a zebrafish semaphorin reveals potential functions in vivo. Dev Dyn 214:13-25.

Harris WA, Holt CE, Bonhoeffer F (1987) Retinal axons with and without their somata, growing to and arborizing in the tectum of Xenopus embryos: a time-lapse video study of single fibres in vivo. Development 101:123-133.

He Z, Tessier-Lavigne M (1997) Neuropilin is a receptor for the axonal chemorepellent Semaphorin III. Cell 90:739-751.

Heffner CD, Lumsden AG, O'Leary DD (1990) Target control of collateral extension and directional axon growth in the mammalian brain. Science 247:217-220.

Hemmati-Brivanlou A, de la Torre J, Holt C, Harland R (1991) Cephalic expression and molecular characterisation of Xenopus En-2. Development 111:715-724.

Holt CE (1984) Does timing of axon outgrowth influence initial retinotectal topography in Xenopus? J Neurosci 4:1130-1152.

Hopker VH, Shewan D, Tessier-Lavigne M, Poo M, Holt C (1999) Growth-cone attraction to netrin-1 is converted to repulsion by laminin-1. Nature 401:69-73.

Kalil K, Szebenyi G, Dent EW (2000) Common mechanisms underlying growth cone guidance and axon branching. J Neurobiol 44:145-158.

Kameyama T, Murakami Y, Suto F, Kawakami A, Takagi S, Hirata T, Fujisawa H (1996) Identification of a neuronal cell surface molecule, plexin, in mice. Biochem Biophys Res Commun 226:524-529.

Kawakami A, Kitsukawa T, Takagi S, Fujisawa H (1996) Developmentally regulated expression of cell surface protein, neuropilin, in the mouse nervous system. J Neurobiol 29:1-17.

Kolodkin AL (1996) Growth cones and the cues that repel them. Trends Neurosci 19:507-513.

Kolodkin AL, Levengood DV, Rowe EG, Tai YT, Giger RJ, Ginty DD (1997) Neuropilin is a semaphorin III receptor. Cell 90:753-762.

Lohof AM, Quillan M, Dan Y, Poo MM (1992) Asymmetric modulation of cytosolic cAMP activity induces growth cone turning. J Neurosci 12:1253-1261.

Luo Y, Raible D, Raper JA (1993) Collapsin: a protein in brain that induces the collapse and paralysis of neuronal growth cones. Cell 75:217-227.

Luo Y, Shepherd I, Li J, Renzi MJ, Chang S, Raper JA (1995) A family of molecules related to collapsin in the embryonic chick nervous system. Neuron 14:1131-1140.

Messersmith EK, Leonardo ED, Shatz CJ, Tessier-Lavigne M, Goodman CS, Kolodkin AL (1995) Semaphorin III can function as a selective chemorepellent to pattern sensory projections in the spinal cord. Neuron 14:949-959.

Ming GL, Song HJ, Berninger B, Holt CE, Tessier-Lavigne M, Poo MM (1997) cAMP-dependent growth cone guidance by netrin-1. Neuron 19:1225-1235.

Murakami Y, Suto F, Shimizu M, Shinoda T, Kameyama T, Fujisawa H (2001) Differential expression of plexin-A subfamily members in the mouse nervous system. Dev Dyn 220:246-258.

Nieukoop PD, Faber J (1967) The normal tables of Xenopus laevis (Daundin). Amsterdam: North Holland Publishing.

Niwa H, Yamamura K, Miyazaki J (1991) Efficient selection for highexpression transfectants with a novel eukaryotic vector. Gene 108:193-199.

Ohta K, Takagi S, Asou H, Fujisawa H (1992) Involvement of neuronal cell surface molecule B2 in the formation of retinal plexiform layers. Neuron 9:151-161.
Ohta K, Mizutani A, Kawakami A, Murakami Y, Kasuya Y, Takagi S, Tanaka H, Fujisawa H (1995) Plexin: a novel neuronal cell surface molecule that mediates cell adhesion via a homophilic binding mechanism in the presence of calcium ions. Neuron 14:1189-1199.

Ohta K, Tannahill D, Yoshida K, Johnson AR, Cook GM, Keynes RJ (1999) Embryonic lens repels retinal ganglion cell axons. Dev Biol 211:124-132.

Pasterkamp RJ, De Winter F, Holtmaat AJ, Verhaagen J (1998) Evidence for a role of the chemorepellent semaphorin III and its receptor neuropilin-1 in the regeneration of primary olfactory axons. J Neurosci 18:9962-9976.

Polleux F, Morrow T, Ghosh A (2000) Semaphorin 3A is a chemoattractant for cortical apical dendrites. Nature 404:567-573.

Puschel AW, Adams RH, Betz H (1995) Murine semaphorin D/collapsin is a member of a diverse gene family and creates domains inhibitory for axonal extension. Neuron 14:941-948.

Raper JA, Kapfhammer JP (1990) The enrichment of a neuronal growth cone collapsing activity from embryonic chick brain. Neuron 4:21-29.

Renzi MJ, Wexler TL, Raper JA (2001) Olfactory sensory axons expressing a dominant-negative semaphorin receptor enter the CNS early and overshoot their target. Neuron 28:437-447.

Rohm B, Ottemeyer A, Lohrum M, Puschel AW (2000) Plexin/neuropilin complexes mediate repulsion by the axonal guidance signal semaphorin 3A. Mech Dev 93:95-104.

Shimamura K, Hirano S, McMahon AP, Takeichi M (1994) Wnt-1dependent regulation of local E-cadherin and alpha N-catenin expression in the embryonic mouse brain. Development 120:2225-2234.

Shirasaki R, Katsumata R, Murakami F (1998) Change in chemoattractant responsiveness of developing axons at an intermediate target. Science 279:105-107.

Shoji W, Yee CS, Kuwada JY (1998) Zebrafish semaphorin Z1a collapses specific growth cones and alters their pathway in vivo. Development 125:1275-1283.

Song H, Ming G, He Z, Lehmann M, Tessier-Lavigne M, Poo M (1998) Conversion of neuronal growth cone responses from repulsion to attraction by cyclic nucleotides. Science 281:1515-1518.

Straznicky K, Gaze RM (1972) The development of the tectum in Xenopus laevis: an autoradiographic study. J Embryol Exp Morphol 28:87-115.

Takagi S, Tsuji T, Amagai T, Takamatsu T, Fujisawa H (1987) Specific cell surface labels in the visual centers of Xenopus laevis tadpole identified using monoclonal antibodies. Dev Biol 122:90-100.

Takagi S, Hirata T, Agata K, Mochii M, Eguchi G, Fujisawa H (1991) The A5 antigen, a candidate for the neuronal recognition molecule, has homologies to complement components and coagulation factors. Neuron 7:295-307.

Takagi S, Kasuya Y, Shimizu M, Matsuura T, Tsuboi M, Kawakami A, Fujisawa H (1995) Expression of a cell adhesion molecule, neuropilin, in the developing chick nervous system. Dev Biol 170:207-222.

Takahashi T, Nakamura F, Jin Z, Kalb RG, Strittmatter SM (1998) Semaphorins A and E act as antagonists of neuropilin-1 and agonists of neuropilin-2 receptors. Nat Neurosci 1:487-493.

Takahashi T, Fournier A, Nakamura F, Wang LH, Murakami Y, Kalb RG, Fujisawa H, Strittmatter SM (1999) Plexin-neuropilin-1 complexes form functional semaphorin-3A receptors. Cell 99:59-69.

Tamagnone L, Artigiani S, Chen H, He Z, Ming GI, Song H, Chedotal A Winberg ML, Goodman CS, Poo M, Tessier-Lavigne M, Comoglio PM (1999) Plexins are a large family of receptors for transmembrane, secreted, and GPI-anchored semaphorins in vertebrates. Cell 99:71-80.

Taniguchi M, Yuasa S, Fujisawa H, Naruse I, Saga S, Mishina M, Yagi T (1997) Disruption of semaphorin III/D gene causes severe abnormality in peripheral nerve projection. Neuron 19:519-530.

Tessier-Lavigne M, Goodman CS (1996) The molecular biology of axon guidance. Science 274:1123-1133.

Tuttle R, O'Leary DD (1998) Neurotrophins rapidly modulate growth cone response to the axon guidance molecule, collapsin-1. Mol Cell Neurosci 11:1-8.

Varela-Echavarria A, Tucker A, Puschel AW, Guthrie S (1997) Motor axon subpopulations respond differentially to the chemorepellents netrin-1 and semaphorin D. Neuron 18:193-207.

Wang KH, Brose K, Arnott D, Kidd T, Goodman CS, Henzel W, Tessier-Lavigne M (1999) Biochemical purification of a mammalian slit protein as a positive regulator of sensory axon elongation and branching. Cell 96:771-784.

Weeks BS, Papadopoulos V, Dym M, Kleinman HK (1991) cAMP promotes branching of laminin-induced neuronal processes. J Cell Physiol 147:62-67.

Yee CS, Chandrasekhar A, Halloran MC, Shoji W, Warren JT, Kuwada JY (1999) Molecular cloning, expression, and activity of zebrafish semaphorin Z1a. Brain Res Bull 48:581-593.

Zheng JQ, Felder M, Connor JA, Poo MM (1994) Turning of nerve growth cones induced by neurotransmitters. Nature 368:140-144.

Z ou Y, Stoeckli E, Chen H, Tessier-Lavigne M (2000) Squeezing axons out of the gray matter: a role for slit and semaphorin proteins from midline and ventral spinal cord. Cell 102:363-375. 